\title{
Mysterium Loth \\ Joachim z Fiore wobec XII-wiecznej teologii spekulatywnej
}

\section{Wprowadzenie}

W piątej księdze Concordia Novi ac Veteris Testamenti Joachim z Fiore (1135-1202) nawiązuje do biblijnego opowiadania o mężczyznach z Sodomy, którzy otoczyli dom Lota, żądając od niego wydania dwóch aniołów przebywających wewnątrz ${ }^{1}$. Opat z Fiore we właściwy sobie sposób interpretuje rozpaczliwy pomysł Lota, który, troszcząc się przede wszystkim o zachowanie świętego prawa gościnności, zamiast aniołów zaproponował zdegenerowanym mieszkańcom Sodomy swoje własne córki, które ,jeszcze nie żyły z mężczyzną":

Jeśli sprawia wam przyjemność posiadanie słuchaczy waszej nauki, w których uszy wlewacie doktrynę waszych sztuk, a mając na uwadze rozgłos, nie możecie jej pokornie utrzymać w zaciszu waszych serc - proszę, są tu u nas ludzie świeccy - weźcie ich sobie i uczcie, i napełniajcie ich wyuzdaniem waszych pragnień! Mężom zaś duchowym, żyjącym na niebiański sposób, pozwólcie odejść w pokoju i bez przeszkód, by czasem nam nie zostało poczytane za powód do oskarżenia, jeśli, pozostając pod naszym dachem, doznaliby takiej krzywdy².

${ }^{1}$ Zob. Joachim von Fiore, Concordia Novi ac Veteris Testamenti, V, 1, 2, 15, red. A. Patschovsky, t. 3, Monumenta Germaniae Historica. Quellen zur Geistesgeschichte des Mittelalters, 28/3, Wiesbaden 2017, s. 624-625; Rdz 19, 4-8.

2 ,Si vos delectat habere discipulos in scientia vestra, in quorum auribus effundatis doctrinam artium vestrarum, quam, ut vobis faciatis nomen, in secretario cordium vestrorum continere humili- 
Trudno nie zauważyć, że dla Joachima z Fiore ten biblijny epizod, poprzedzający spektakularne zniszczenie Sodomy i Gomory „,deszczem ognia i siarki od Pana”, staje się okazją do refleksji nad życiem umysłowym w XII wieku³. Biorąc pod uwagę punkt wyjścia Joachimowej egzegezy, jakim są tragiczne losy dwóch miast, będących odtąd symbolem głębokich wynaturzeń w dziedzinie seksualności, nie sposób nie dojść do wniosku, że stosunek opata z Fiore do owych wyuzdanych mistrzów, których protoplastami są skazani ostatecznie na zagładę mieszkańcy Sodomy, jest jednoznacznie negatywny; przypomina też znane diatryby innego XII-wiecznego autora, Bernarda z Clairvaux, wymierzone w ówczesnych mistrzów, uprawiających naukę dla samej nauki, co jest tylko „bezwstydną ciekawością” (turpis curiositas) i „bezwstydną próżnością" (turpis vanitas) ${ }^{4}$.

Za stanowiskiem Bernarda z Clairvaux stoi przyjęta przez niego antropologia, która z kolei rzutuje na jego mistykę. Jak twierdzi Stefan Swieżawski, przykładem tego „uwikłania” Bernardowej mistyki w problemy psychologiczne i filozoficzne jest kwestia wolnej woli ${ }^{5}$. Grzech pierworodny spowodował, że wolność woli doznała znacznego uszczerbku i odtąd człowiek gubi się na drodze ku właściwemu sobie szczęściu, którym jest Bóg, i sam skazuje się na pobyt $\mathrm{w}$ „krainie niepodobieństwa do Boga”. Wyjściem z tego stanu, który przypomina „krainę, gdzie wszystko jest inaczej” (regio dissimilitudinis) z Wyznań św. Augustyna, jest uzdrowienie chorej woli, która stała się egoistyczną samowolą, stawiającą swoje ja ponad Bogiem? Należy najpierw wykorzenić z duszy egoizm (proprium consilium) i zastąpić go prawdą, której szukać należy w wierze, wpajającej nam pokorę. Dopiero wtedy, w miejsce egoistycznej samowoli, zamieszka w duszy miłość, która

ter non potestis - ecce, sunt apud nos simplices et ydiote, illos assumite et docete, et in illis implete libidinem desideriorum vestrorum! Viros autem spiritales, quorum conversatio in celis est, in pace dimittite et quiete, ne hos ipsum iam nobis reputetur in crimen, si manentes apud nos talem iniuriam patiuntur!" - Joachim von Fiore, tamże, s. 624; por. Księga Rodzaju. Wstęp - przekład z oryginałukomentarz, oprac. S. Łach, Poznań 1962, s. 376.

${ }^{3}$ Zob. Rdz 19,24.

${ }^{4}$ „Sunt namque qui scire volunt eo fine tantum, ut sciant: et turpis curiositas est. Et sunt qui scire volunt, ut sciantur ipsi: et turpis vanitas est" - Sancti Bernardi abbatis clarae-vallensis sermones in Cantica Canticorum, 36, 3, red. H. Hurter, Sanctorum Patrum opuscula selecta ad usum praesertim studiosorum theologiae, series altera, 5, Oeniponte 1888, s. 319; zob. S. Swieżawski, Dzieje europejskiej filozofii klasycznej, Warszawa-Wrocław 2000, s. 536.

${ }^{5}$ Zob. S. Swieżawski, Dzieje europejskiej filozofii klasycznej, s. 535.

${ }^{6}$ „Porro ad se humiliandum nihil anima invenire vivacius seu accomodatius potest, quam si se in veritate invenerit: tantum non dissimulet, non sit in spiritu ejus dolus, statuat se ante faciem suam, nec se a se avertere abducatur. Nonne se ita intuens clara luce veritatis, inveniet se in regione dissimilitudinis: et suspirans misera, quam jam latere non poterit quod vere misera sit, nonne cum propheta clamabit ad Dominum: In veritate tua humiliasti me (Ps. 118, 75)" - Sancti Bernardi abbatis claraevallensis sermones in Cantica Canticorum, 36, 5, s. 321.

${ }^{7}$ Zob. Augustyn, Wyznania, VII, 10, tłum. Z. Kubiak, Kraków 1997, s. 151. 
naprawi zdeformowany obraz Boga ${ }^{8}$. Nie uczyni tego - zdaniem Bernarda ani przeniknięta pychą ciekawość Abelarda, ani niewiele warte wielomówstwo filozofów (ventosa loquacitas philosophorum); to ostatnie jest jak niedobry deszcz, który zamiast użyźniać ziemię, sprawia, że staje się jałowa9. Warto w tym miejscu dodać, że dla Bernarda z Clairvaux, oprócz pełnej pychy ludzkiej mądrości, na ziemię spadają też toksyczne deszcze heretyckich doktryn (prava dogmata haereticorum), rodzące ciernie i osty; podobnie było w przypadku zwalczanych przez Pana Jezusa tradycji faryzeuszów (traditiones pharisaeorum). Ponadto, pozostając $\mathrm{w}$ kręgu symboliki zjawisk atmosferycznych, Bernard nie waha się porównać Prawa Mojżeszowego do toksycznej chmury i argumentuje, że to, co było dobre w swoim czasie, przestało takim być obecnie ${ }^{10}$.

Miłość (charitas) sprawia, że pragnący wiedzy potrafi ukierunkować to pragnienie ku dobru, wystrzegając się jednocześnie nadużywania wiedzy dla osiągnięcia złych celów ${ }^{11}$. Ujęta $\mathrm{w}$ ten sposób intencja działającego sprawia, że jego działanie uzyskuje dzięki miłości wymiar ściśle moralny, co sprawia, że rozważania Bernarda z Clairvaux, zawarte w kazaniach poświęconych Pieśni nad Pieśniami, sytuują się w głównym nurcie chrześcijańskiej etyki. Jeśli dodać do tego symbolikę oblubieńczą i piękno autentycznej miłości, to Bernard krytykujący to, co uważa za nadużycia występujące w XII-wiecznym życiu intelektualnym, jawi się jako autor, którego spuścizna stanowi dobre wprowadzenie do problematyki podjętej w niniejszym artykule, a jest nią stosunek Joachima z Fiore do współczesnej mu teologii spekulatywnej ${ }^{12}$.

${ }^{8}$ Zob. S. Swieżawski, Dzieje europejskiej filozofii klasycznej, s. 536.

9 „Philosophorum ventosa loquacitas non bonus imber est, qui sterilitatem magis intulit terris, quam fertilitatem" - Sancti Bernardi abbatis clarae-vallensis sermones in Cantica Canticorum, 58,7, s. 479.

${ }^{10}$ „Fuerit sane bona suo tempore: post tempus si venerit, non bonam jam censeo. Omnis etiam lenia et leniter descendens pluvia, si sit intempestiva, molesta est" - tamże.

${ }^{11}$ „Et sunt item qui scire volunt, ut scientiam suam vendant, verbi causa, pro pecunia, pro honoribus: et turpis quaestus est. Sed sunt quoque qui scire volunt, ut aedificent: et charitas est. Et item qui scire volunt, ut aedificentur: et prudentia est. Horum omnium soli ultimi duo non inveniuntur in abusione scientiae, quippe ad hoc volunt intelligere, ut bene faciant" - tamże, 36, 3-4, s. 319; por. 1 Kor 13,4-5.

${ }^{12}$ Przynależność Joachima do zakonu cystersów, a także ogromny autorytet, jakim cieszył się Bernard z Clairvaux, kanonizowany w 1174 roku, mogą sugerować, że wpływ tego ostatniego na opata z Fiore był czymś oczywistym. W swoim komentarzu Janowej Apokalipsy (Expositio in Apocalypsim) Joachim wyraża się z ogromnym szacunkiem o swoim znakomitych współbracie (beatus Bernardus Abbas Clarevallis, qui vita, miraculis et scientia singulariter in diebus nostris illustravit ecclesiam). Bernard jawi się w Joachimowej spuściźnie nie tylko jako święty mnich, utalentowany autor i pogromca herezji, lecz zajmuje również ważne miejsce w teologii dziejów opata z Fiore. Bernard z Clairvaux jako „nowy Mojżesz” (alter Moyses) wchodzi na górę kontemplacji, odgrywa opatrznościową rolę w dziejach duchowych synów św. Benedykta, dając impuls do ogromnego wzrostu duchowego i liczebnego wspólnoty cysterskiej, założonej przez Roberta z Molesmes: „, [...] 
Przywołany wyżej Stefan Swieżawski zaznacza, że w średniowieczu filozofia została wprzęgnięta w teologię, stąd samo ,pojęcie «teologia spekulatywna» było bardzo szeroko rozumiane. Do teologii została wcielona nie tylko filozofia, ale i inne nauki były w niej zawarte i jej podporządkowane. Dlatego trudno je nieraz wydobyć i poznać, ponieważ są przemieszane w jednej retorcie teologicznej. Tego zjawiska nie spotkamy w innych epokach i stąd wynikają trudności w pojmowaniu istoty wieków średnich" ${ }^{3}$. Próbując uściślić zakres pojęcia „teologia spekulatywna”, można stwierdzić, że ma ona charakter teoretyczny w tym, co dotyczy stojących przed nią zadań, a jej cel, zwany spekulatywnym, zamyka się w haśle fides quaerens intellectum lub intelligere quod creditur i jest osiągany na drodze rozumowania opierającego się na niezawodnych regułach wynikania ${ }^{14}$.

Choć w ubiegłym wieku postać i spuścizna Joachima z Fiore doczekały się pogłębionej analizy ze strony mediewistów, to jednak ten XII-wieczny autor nadal jawi się jako swego rodzaju outsider, daleki od dominujących nurtów

vir quidam bonus et timens Deum egressus est a cenobio molismensi, cuius erat et Abbas, cum hiis, qui inspirati divinitus secuti sunt eum, et pervenit in solitudinem Cistercii, ubi, edificato monasterio, cisterciensis ordinis fundamenta iactavit. Mansit autem eadem domus sterilis et infecunda quasi per annos quatuordecim, et tunc demum abbati ipsius domus, qui errat tertius a primo, dati sunt filii desiderii sui benedicente Domino eidem domui ad introitum sancti viri Bernardi et fratrum eius et aliorum, qui relicto seculo intraverunt cum eo, adeo ut in ea tunc temporis propheticum illud videretur esse completum: Letare, sterilis, que non paris, decanta laudem, et hinni, que non pariebas, quoniam multi filii deserte, magis quam eius, que habet virum! Ut enim ostenderet Dominus, vir ille qualis et quantus esset futurus, et mirabiliter natus est matri secundum carnem et mirabilius prescripte domus factus est filius spiritalis, ut quasi alter Levi et alter Moyses esse in ortu et in doctrine gratia videretur" - Joachim von Fiore, Concordia Novi ac Veteris Testamenti, IV, 2, 2, 16-17, red. A. Patschovsky, t. 2, Monumenta Germaniae Historica. Quellen zur Geistesgeschichte des Mittelalters, 28/2, Wiesbaden 2017, s. 491-492; Iz 54,1.

Bernard jako alter Levi nawiązuje do Joachimowej zgodności (concordia) Starego i Nowego Testamentu, gdzie Lea odpowiada matce opata z Clairvaux, który, podobnie jak Lewi, urodził się jako jej trzecie dziecko (por. Rdz 29,34). Mimo ugruntowanej pozycji, jaką Bernard z Clairvaux zajmował w Joachimowej teologii dziejów, od lat osiemdziesiątych XII wieku opat z Fiore zaczął postrzegać cystersów, a więc także ich wybitnego przedstawiciela, jako „moment” w dziejach życia monastycznego, który pod naciskiem bliskiej już apokalipsy musi ustąpić miejsca wspólnocie zdolnej stawić czoła nadchodzącym ostatecznym zmaganiom. Na temat roli Bernarda z Clairvaux w refleksji Joachima z Fiore - zob. Ioachim abbas Florensis, Tractatus in expositionem vite et regule beati Benedicti cum appendice fragmenti (I) de duobus prophetis in novissimis diebus praedicaturis, red. A. Patschovsky, Fonti per la storia dell'Italia medievale. Antiquitates, 29, Roma 2008, s. 156-157; B. McGinn, ,'Alter Moyses”: il ruolo di Bernardo di Clairvaux nel pensiero di Gioacchino da Fiore, „Florensia. Bollettino del Centro Internazionale di Studi Gioachimiti” 5 (1991), s. 7-25; V. De Fraja, Oltre Cîteaux. Gioacchino da Fiore e l'ordine florense, Opere di Gioacchino da Fiore: testi e strumenti, 19, Roma 2006.

${ }_{13}$ S. Swieżawski, Dzieje europejskiej filozofii klasycznej, s. 399.

${ }_{14}$ Zob. A. Bronk, S. Majdański, Teologia - próba metodologiczno-epistemologicznej charakterystyki, „Nauka” 2 (2006), s. 96-97; J.D. Szczurek, Spekulatywna teologia, w: Encyklopedia katolic$k a$, t. 18, red. E. Gigilewicz, Lublin 2013, kol. 658. 
średniowiecznej teologii ${ }^{15}$. Z pewnością wpływ na ten stan rzeczy miały pierwsze próby spojrzenia na fenomen tego kalabryjskiego myśliciela i akcentowanie związków, jakie zachodzą pomiędzy jego twórczością a środowiskiem, w którym żył i pisał. Obraz XII-wiecznej Kalabrii, pojawiający się w pracach historyków z pierwszej połowy ubiegłego wieku, charakteryzowała surowość oddalonych od ówczesnych miast leśnych i górskich zakątków, naznaczonych obecnością mnichów bazyliańskich, a co za tym idzie, cywilizacji bizantyjskiej $^{16}$. Jeszcze $\mathrm{w}$ drugiej połowie XX wieku autorzy podejmujący refleksję nad Joachimową spuścizną upatrują w ,prowincjonalizmie” opata z Fiore powodu, dla którego miałby się, między innymi, zdystansować od rodzącej się wówczas scholastyki, będącej zjawiskiem charakterystycznym dla średniowiecznych miast ${ }^{17}$. Jak zauważa Gian Luca Potestà, „Joachim z Fiore przez długi czas był postrzegany jako rodzaj dzikiego i samotnego apokaliptyka""18.

Skok jakościowy w badaniach nad spuścizną Joachima z Fiore, z czym mamy do czynienia pod koniec XX i na początku XXI wieku, oraz publikacja edycji krytycznych jego dzieł, pozwalają na szczegółową ocenę stosunku Joachima do XII-wiecznej teologii spekulatywnej. Punktem wyjścia badań, których wyniki zostały zawarte w niniejszym artykule, jest przywołany wyżej fragment piątej księgi Joachimowej Concordia Novi ac Veteris Testamenti, zawierający charakterystyczną dla tego autora interpretację historii starotestamentalnego Lota. W piątej księdze tego kluczowego dla wypracowanej

${ }^{15}$ Bernard McGinn stwierdza: „When we ask the question, «What was Joachim's place in twelfth-century theology?», one answer that is likely to spring to mind is that the Abbot of Fiore was the great «outsider» in relations to the main currents that shaped much twelfth-century thought" B. McGinn, Ratio and Visio: Reflections on Joachim of Fiore's Place in Twelfth-Century Theology, w: Gioacchino da Fiore tra Bernardo di Clairvaux e Innocenzo III. Atti del $5^{\circ}$ Congresso internazionale di studi gioachimiti, San Giovanni in Fiore - 16-21 settembre 1999, red. R. Rusconi, Opere di Gioacchino da Fiore: testi e strumenti, 13, Roma 2001, s. 27.

${ }^{16}$ Przykładem tego typu „romantycznego” podejścia do postaci i spuścizny Joachima z Fiore jest twórczość E. Anitchkova (1866-1937) - zob. E. Anitchkof, Joachim de Flore et les milieux courtois, Roma 1931. W 1937 roku Kalabria stała się celem podróży, jaką podjął inny rosyjski pisarz, poeta i krytyk literacki Dymitr Mierieżkowski (1865-1941). Wyprawa w trudno wówczas dostępne miejsca związane z Joachimem z Fiore miała na celu zakosztowanie panującego w nich duchowego klimatu - zob. C. Balistreri, La figura di Gioacchino da Fiore nell'opera di D.S. Merežkovskij, w: Gioacchino da Fiore nella cultura contemporanea. Atti del $6^{\circ}$ Congresso internazionale di studi gioachimiti, San Giovanni in Fiore - 23-25 settembre 2004, red. G.L. Potestà, Opere di Gioacchino da Fiore: testi e strumenti, 17, Roma 2005, s. 127-141.

${ }^{17}$ Podsumowując swoje rozważania na temat miejsca Joachima z Fiore w XII-wiecznej kulturze teologicznej, Henri Mottu stwierdza: „Bref, Joachim est sociologiquement un retardataire, même par rapport aux nouveaux mouvements de rénovation de la seconde moitié du XII siècle, précédant l'éclosion des ordres mendiants" - H. Mottu, La manifestation de l'Esprit selon Joachim de Fiore. Herméneutique et théologie de l'histoire d'après le „,Traité sur les Quatre Evangiles”, NeuchâtelParis 1977, s. 22.

${ }^{18}$ Zob. G.L. Potestà, Il tempo dell'Apocalisse. Vita di Gioacchino da Fiore, Roma-Bari 2004, s. 8 . 
przez siebie teologii dziejów traktatu opat z Fiore zastosował do interpretacji wybranych i znaczących epizodów biblijnych (gesta sollempniora) rozwiniętą $\mathrm{w}$ poprzednich księgach hermeneutykę, opartą na teorii sensów biblijnych i zbudowaną wokół znaczeń, jakie niosą ze sobą „cztery istoty żyjące” w wizji proroka Ezechiela oraz cztery „Zwierzęta” z Janowej Apokalipsy ${ }^{19}$.

Ezechielowa wizja jest na wskroś dynamiczna: „Każda [z czterech istot żyjących - J.G.] posuwała się prosto przed siebie; szły tam, dokąd je duch prowadził; idąc, nie odwracały się" (Ez 1,12). Dynamika ta przybiera u Joachima z Fiore postać procesu historycznego, mającego Ducha Świętego za przewodnika. W niniejszym artykule chcemy przyjrzeć się z bliska konsekwencjom tego podejścia do dziejów i udzielić odpowiedzi na pytanie o stosunek Joachima z Fiore do XII-wiecznej teologii spekulatywnej. Jest to w gruncie rzeczy pytanie o metodę, jaką posługuje się kalabryjski opat w głównym nurcie swojej twórczości, a co za tym idzie, o źródło pewności, z jaką występuje wobec osób sobie współczesnych, którym jawił się przede wszystkim jako prorok zapowiadający przyszłe wydarzenia ${ }^{20}$.

Niniejszy artykuł składa się z dwóch części. W pierwszej zebrano i poddano analizie wybrane fragmenty Joachimowej spuścizny, w której mamy do czynienia z krytyką teologii scholastycznych mistrzów. Rdzeniem refleksji jest jednak część druga, stanowiąca jej pars construens i mająca na celu wyjaśnienie motywów, jakie wpłynęły na postawę opata z Fiore wobec XII-wiecznej teologii spekulatywnej. Autor ma świadomość, że czytelnik może być zaskoczony pojawieniem się starotestamentalnej postaci Lota w kontekście Joachimowej oceny życia intelektualnego w średniowieczu. Zaskoczenie szybko mija, kiedy pozwolimy się poprowadzić wizji dziejów, jaka wyłania się

19 „Quatuor concordiarum libri, quos hucusque digessimus, ita secundum numerum quatuor animalium accipiantur in specie, ut primus, in quo simpliciter compilantur historie, referatur ad hominem; secundus, in quo agitur de precipuis et evidentioribus locis concordiarum, referatur ad vitulum; tertius, in quo agitur de concordiis septem signaculorum, referatur ad leonem; quartus, in quo agitur de plenitudine concordie, referatur ad aquilam. Etenim in hiis quatuor libris parum agitur secundum spiritum, magis autem secundum litteram, hoc est secundum concordiam littere et littere duorum scilicet Testamentorum. Quia vero post quatuor illa magna opera Christi - quibus se nascendo, patiendo, resurgendo necnon et ascendendo in celum quatuor animalibus conformavit - nonnisi in quinto ordine ignis est ostensus divinus, secundum quod et de ipsis verbis historicis spiritales prodeunt intellectus, oportet nos in hoc quinto libro de quibusdam gestis sollempnioribus, que occurrerint spiritaliter agere, ut ex multis testimoniis ostendamus laboriosos rerum fines, et post magnos agones et certamina pacem victoribus impartiri" - Joachim von Fiore, Concordia Novi ac Veteris Testamenti, V, 1, 1, 1, s. 505-506; por. Ez 1,5-12; Ap 4,6-11; zob. Joachim von Fiore, Concordia Novi ac Veteris Testamenti, red. A. Patschovsky, t. 1, Monumenta Germaniae Historica. Quellen zur Geistesgeschichte des Mittelalters, 28/1, Wiesbaden 2017, s. CXLIV-CXLVII.

20 „Tutaj promienny błyszczy przy mym boku / Joachim, opat z Kalabrii, co gmina / cała wie o nim jako o proroku" - Dante Alighieri, Boska Komedia, Raj, XII, 139-141, thum. A. Świderska, Kęty 1999, s. 453. 
z długoletniej pracy opata z Fiore jako egzegety oraz jego mistycznych intuicji, skupionych wokół tajemnicy trynitarnej ${ }^{21}$.

\section{Wobec rodzącej się scholastyki}

W dziełach Joachima z Fiore nie brak krytyki pod adresem „filozofów”, podobnej do tej, jaką znaleźć można w twórczości Bernarda z Clairvaux. W Psalterium decem cordarum Aaron jest, według Joachimowej typologii, typem człowieka wykształconego, mającego łatwość przemawiania (vir scolasticus habens linguam eruditam). Typem człowieka biegłego w sprawach ducha (doctor spiritalis) jest Mojżesz ${ }^{22}$. Współpraca pomiędzy tym, który rozumie, i tym, który mówi, może być niezwykle owocna ${ }^{23}$. Wydaje się jednak, że na tym kończy się pozytywny wydźwięk słowa scolasticus, widoczny w dziełach Joachima z Fiore. W swoim późnym dziele, znanym jako Tractatus super quatuor evangelia, opat pochyla się jako egzegeta nad spotkaniem Jezusa z Samarytanką przy studni, porównując zdziwienie uczniów na widok Zbawiciela rozmawiającego z kobietą do postawy tych, którzy - wypełnieni po brzegi szkolną wiedzą (hii, qui scolastica inflantur scientia) - zwykli się dziwić, widząc mężów duchowych, jak rozmawiają z ludźmi prostymi lub dalekimi od wiary katolickiej, nie mogąc pojąć, że jest czymś powszechnym wśród ludzi przez nich pogardzanych to, do czego rościli sobie pretensje i uważali za przynależne tylko $\mathrm{im}^{24}$.

${ }^{21}$ Zob. J. Grzeszczak, Czy Joachim z Fiore byt mistykiem? Kilka uwag na temat apokaliptycznej duchowości kalabryjskiego opata, „Filozofia Chrześcijańska” 15 (2018), s. 59-81.

${ }^{22}$ Zob. Joachim von Fiore, Psalterium decem cordarum, II, IV, 4, red. K.V. Selge, Monumenta Germaniae Historica. Quellen zur Geistesgeschichte des Mittelalters, 20, Hannover 2009, s. 280.

${ }^{23}$ „Qui duo, dum sibi conveniunt in vinculo pacis, ut quod unus intelligit, alius loquatur, eripiunt spiritales intellectus et eos quibus datum est posse capere eos a potestate heresum, et per multos scribendi labores perducunt illos ad notitiam veritatis" - tamże; por. Wj 4,15; Ef 4,3; Mt 19,11.

${ }^{24}$ Zob. Ioachim abbas Florensis, Tractatus super quatuor evangelia, III, 16, red. F. Santi, Fonti per la storia dell'Italia medievale. Antiquitates, 17, Roma 2002, s. 302; J 4,27. Na niewystarczalność dialektyki wskazuje - zdaniem Joachima z Fiore - fragment Janowej Ewangelii, gdzie mowa o braku wina na weselu w Kanie Galilejskiej (zob. J 2,3): „Interpellat ergo MATER IESU pro convivantibus, UT DEFICIENTE qualicumque vINO, quod veluti de natura provenerat, ostenderetur vinum veritatis, quia «deficiente» in inveniendo quod queritur - multa enim adhuc queruntur, que difficile inveniuntur scolastica doctrina - innuet quodammodo mater Filio (sed tamen non vir, sed mulier viro), ut doctrina illa spiritali imbuantur convive, cuius perfectione evacuetur quod ex parte est, et fiat in eis, ut alterum tangam misterium, fons aque salientis in vitam eternam" - Ioachim abbas Florensis, Tractatus super quatuor evangelia, I, 9, s. 205; por. 1 Kor 13,10; J 4,14. Na wyższość duchowej doktryny nad dialektyką opat wskazuje także, zestawiając uczniów Jana Chrzciciela z uczniami Jezusa: ,„[...] in discipulis Iohannis designantur hii qui scolastica instituuntur doctrina, in discipulis Iesu hii qui erudiuntur et imbuuntur spiritali" - Ioachim abbas Florensis, Tractatus super quatuor evangelia, III, 16, s. 286-287. 
Jak łatwo zauważyć, powyższe stwierdzenia są echem Pawłowych słów o wiedzy, która wbija w pychę, gdy ktoś, kto ją ma, ,nie wie, jak wiedzieć należy" (1 Kor 8,2). W podobny sposób Joachim interpretuje Chrystusowe słowa o ,prostaczkach”, którym Ojciec objawił swoje zamiary, zakrywając je przed „mądrymi i roztropnymi” i dystansując się w ten sposób od „Wszelkiej próżności filozoficznego przesądu” (omnis philosophicae superstitionis vanitas $)^{25}$. Trudno $\mathrm{w}$ tym miejscu nie dostrzec aluzji do pojawiającej się w XII wieku w środowiskach monastycznych krytyki ówczesnego życia intelektualnego. Jak twierdzi Giles Constable, jej ostrze było wymierzone przede wszystkim w naukę uprawianą poza klasztorami ${ }^{26}$. Amerykański autor podaje przykłady konkretnych autorów, niechętnych lub wręcz wrogich wobec XII-wiecznych szkół: Ruperta z Deutz i jego spór z mistrzami z Laon, Piotra Czcigodnego czy Bernarda z Clairvaux, przeciwstawiającego się Abelardowi i Gilbertowi de la Porrée ${ }^{27}$. Niechęć Joachima z Fiore wobec metod stosowanych przez ówczesnych mistrzów, rozmiłowanych zwłaszcza w logice, była uwarunkowana monastyczną mentalnością opata, dla którego intelektualna pycha stanowiła zaprzeczenie szczególnie cenionej przez niego cnoty pokory ${ }^{28}$.

${ }^{25}$ Zob. Joachim von Fiore, Concordia Novi ac Veteris Testamenti, II, I, 1, s. 52-53; por. Łk 10,21.

${ }^{26}$,The emphasis on manual labour was sometimes accompanied by a prejudice against other types of work, especially intellectual work outside the monastery. A distrust of secular schools and their methods of teachings was widespread in monastic circles in the twelfth century" - G. Constable, The Reformation of the Twelfth Century, Cambridge 1996, s. 214.

27 Zob. tamże, s. 214-215.

28 Pokora jest dla Joachima cnotę wykraczającą daleko poza indywidualny wymiar pracy nad sobą, charakteryzujący klasztorną duchowość. Dialektyka pokory i pychy jest motorem dziejowych procesów, a Joachim poświęca jej wiele miejsca w swoich mniejszych objętościowo dziełach: Intelligentia super calathis ad abbatem Gafridum, Quaestio de Maria Magdalena et Maria sorore Lazari et Marthae i Dialogi de prescientia Dei et predestinatione electorum. O wadze tego zagadnienia w całokształcie spuścizny opata świadczą również diagramy Roma/Babilonia i Ecclesia/Roma z Liber Figurarum, będące obrazowym streszczeniem Joachimowej wizji dziejów - zob. Ioachim abbas Florensis, Intelligentia super calathis ad abbatem Gafridum, w: tenże, Scripta breviora, red. A. Patschovsky, G.L. Potestà, Fonti per la storia dell'Italia medievale. Antiquitates, 40, Roma 2014, s. 183-217; tenże, Quaestio de Maria Magdalena et Maria sorore Lazari et Marthae, tamże, s. 243-260; Gioacchino da Fiore, Dialoghi sulla prescienza divina e la predestinazione degli eletti, red. G.L. Potestà, Opere di Gioacchino da Fiore: testi e strumenti, 14, Roma 2001; H. Grundmann, Kirchenfreiheit und Kaisermacht um 1190 in der Sicht Joachims von Fiore, „Deutsches Archiv für Erforschung des Mittelalters" 19 (1963), s. 353-396; M. Reeves, B. Hirsch-Reich, The Figurae of Joachim of Fiore, Oxford 1972, s. 184-191; A. Patschovsky, Il diagramma di Gioacchino da Fiore di due alberi Gerusalemme-Babilonia ed Ecclesia-Roma, „Florensia. Bollettino del Centro Internazionale di Studi Gioachimiti" 16-17 (2002-2003), s. 7-23; V. De Fraja, Da Gerusalemme a Babilonia. La tipologia della contrapposizione e della decadenza tra XII e XIII secolo, „Rivista di storia del cristianesimo" 1 (2004), s. 53-59; J. Grzeszczak, Głos teologa w sprawach średniowiecznej polityki. Diagramy Roma i Babilonia oraz ich wymowa doktrynalna i moralna, „Kronos. Metafizyka, Kultura, Religia" 2014, nr 2, s. 122-140; tenże, Moralna wymowa gestu namaszczenia stóp i głowy Jezusa 
W przypadku Joachima negatywny stosunek do dialektyki nabiera charakteru apokaliptycznego. W Expositio in Apocalypsim opat, komentując otwarcie trzeciej pieczęci, pisze o filozofach, którzy na soborze w Nicei posługiwali się przewrotną dialektyką (astutia dialecticae artis), by szkodzić wierze katolickiej ${ }^{29}$. Ten sam temat pojawia się również w Concordia Novi ac Veteris Testamenti, gdzie jeździec siedzący na czarnym koniu (Ap 6,5), mający w ręku wagę, to pozbawieni Chrystusowego światła ariańscy biskupi, którzy za pomocą dialektycznych dysput próbowali rozstrzygać, która z Osób Trójcy Świętej jest większa, a która mniejsza ${ }^{30}$. Tajemniczy ,jakby głos pośrodku czterech Zwierząt, mówiący: «Kwarta pszenicy za denara i trzy kwarty jęczmienia za denara, a nie krzywdź oliwy i wina!»” (Ap 6,6), to - zdaniem Joachima z Fiore - nic innego, jak przywołanie nauki o sensach biblijnych, która jest wyznacznikiem katolickości ${ }^{31}$. Konkludując, po raz kolejny opat z Fiore zwraca uwagę na rolę pokory, która skłania do modlitwy o łaskę zrozumienia i ostatecznie okazuje się skuteczniejsza niż studium (humilitate magis gratiam promerentes quam studio) ${ }^{32}$. Do tego kluczowego dla Joachimowej metody elementu będziemy mieli okazję wrócić w kolejnej części naszych rozważań; w tym miejscu warto dodać, że dla opata granica pomiędzy dialektyką i herezją jest raczej subtelna. Symbolem tego stanu rzeczy jest apokaliptyczny „czarny koń”, pojawiający się po otwarciu trzeciej pieczęci i przynoszący kolejne prześladowanie wiernych Kościoła. Jego kolor oznacza fałszywe doktryny, w tym przypadku arianizm, oraz duchownych, którzy ich nauczają, nazwanych „nauczycielami błędu i ciemności” (erroris et tenebrarum magistri) ${ }^{33}$.

Wydaje się jednak, że upatrywanie w Joachimie wyłącznie apokaliptycznego wizjonera nie uwzględnia całego bogactwa i oryginalności jego teologii, a niezauważenie w niej czynnika racjonalnego prowadziłoby do jej daleko idącego zubożenia. Jak zauważa Bernard McGinn, opat z Fiore miał, podobnie

w Quaestio de Maria Magdalena et Maria sorore Lazari et Marthae Joachima z Fiore, „Vox Patrum” 69 (2018), s. 175-193.

${ }^{29}$ Zob. Expositio magni prophete Abbatis Ioachim in Apocalipsim, Venetiis 1527, f. 115ra.

${ }^{30}$ „Sessor huius equi reges et episcopi arriani fuere. Hec utique persecutio non ab alienis, sicut cetere, sed e medio Ecclesie orta est, que tamen decursis annis in externas convaluit nationes. Qui videlicet arriani episcopi recte stateram in manu baiulasse dicti sunt, quia de Patre et Filio et Spiritu Sancto, quis esset maior an minor, dialecticis disputationibus inquirebant" - Joachim von Fiore, Concordia Novi ac Veteris Testamenti, III, 2, 3, s. 320-321.

${ }^{31}$ Zob. tamże.

${ }^{32}$ Zob. tamże. W Intelligentia super calathis opat z Fiore z naciskiem stwierdza: „Dicit enim in corde suo: «Si Deus iustus est, debet utique adiuvare volentes ambulare in iustificationibus suis.» Quare autem dicit istud? Quia solam prospicit carnis iustitiam, in qua salus non est, et non attendit illam virtutem, ex qua maxime salus et iustitia pendet. Et que est illa? Humilitas!" - Ioachim Abbas Florensis, Intelligentia super calathis ad abbatem Gafridum, 1, s. 203; por. Ps 14,1; 53, 2; Flp 3,4-7.

${ }_{33}$ Zob. Expositio magni prophete Abbatis Ioachim in Apocalipsim, f. 114vb. 
jak Piotr Abelard i inni XII-wieczni dialektycy, świadomość niezastąpionej roli ludzkiego rozumu w dociekaniach teologicznych ${ }^{34}$. Amerykański mediewista przyznaje, co prawda, że w swoich głównych dziełach Joachim milczy na temat aktualnych wówczas kwestii, takich jak siła przekonywania rozumu (cogency of reason) czy relacja wiara - rozum, jednakże w mniejszych traktatach problemy te pojawiają się w sposób bardzo wyraźny ${ }^{35}$. Wymownym tego przykładem są Joachimowe De articulis fidei ad fratrem Iohannem, a zwłaszcza Dialogi de prescientia Dei et predestinatione electorum, w których opat nie tylko zabiera głos na temat tego, co sam określa jako vetustissima questio, czyli relację pomiędzy wiedzą Boga i przeznaczeniem wybranych, lecz także korzysta z narzędzi przypominających Abelardowe sic et non, określając ponadto przyjętą przez siebie formę wykładu mianem disputatio ${ }^{36}$.

Antydialektyczna postawa opata z Fiore przełożyła się nie tylko na teoretyczne rozważania, lecz doprowadziła również do uwikłania się w polemikę z trynitarnymi ujęciami Piotra Lombarda, a następnie, już po śmierci Joachima, do potępienia jego stanowiska na Soborze Laterańskim IV ${ }^{37}$. Joachimowa wizja ma Trójcę Świętą za punkt wyjścia i stąd trynitarne herezje stanowią dla niego zagrożenie, które należy demaskować i zwalczać. Trzy podstawowe błędy trynitarne, jakie pojawiły się na przestrzeni dziejów Kościoła, to - według opata z Fiore - sabelianizm, arianizm i wprowadzenie do Trójcy Świętej czwartego elementu, jakim jest wspólna Osobom istota, co miało być dziełem Piotra Lombarda. W Sentencjach tego ostatniego pojawia się sformułowanie: „Jakąś najwyższą rzeczywistością jest Ojciec, Syn i Duch Święty, a ona nie jest ani rodząca, ani zrodzona, ani pochodząca" ${ }^{38}$. Ojcowie sobo-

34 Zob. B. McGinn, Ratio and Visio, cyt.

35 „By now, you may be wondering what Joachim of Fiore has to do with these well-known discussions of the cogency of reason and the relations of reason and faith characteristic of the twelfth century. The abbot of Fiore does not spend time exploring such issues in his major works, an absence that once again seems to confirm his status as an outsider. But if we look at one of Joachim's lesser known works, we find a suggestive connection between the abbot of Fiore and this broad twelfthcentury problematic" - tamże, s. 32 .

36 Joachim zauważa, że problem ten pojawia się „,na ustach wielu”, i choć przyznaje, że nie można go rozwiązać poprzez wniknięcie w Boże tajemnice celem uzyskania jasnego zrozumienia, to jednak podejmuje ten temat, chcąc przynajmniej wyeliminować sofistyczne argumenty, godzące w wiedzę Boga i przeznaczenie wybranych (obiecta contra ipsa sophistica argumenta devitare)" zob. Gioacchino da Fiore, Dialoghi sulla prescienza divina e la predestinazione degli eletti, I, s. 32, 102; por. Ioachim Abbas Florensis, De articulis fidei ad fratrem Iohannem. Confessio fidei, red. V. De Fraja, Fonti per la storia dell'Italia medievale. Antiquitates, 37, Roma 2012.

37 Zob. konstytucja De errore abbatis Ioachim, w: Dokumenty Soborów Powszechnych. Tekst grecki, łaciński, polski, t. 2 (869-1312), red. A. Baron, H. Pietras, Kraków 2003, s. 224-231; R.E. Lerner, Joachim and the Scholastics, w: Gioacchino da Fiore tra Bernardo di Clairvaux e Innocenzo III, s. 251-264.

38 Zob. Piotr Lombard, Libri IV sententiarum, I, dist. 5, cyt. za: Dokumenty Soborów Powszechnych, t. II, s. 225. 
rowi przywołują zaginiony, najprawdopodobniej niewielki objętościowo traktat (libellus sive tractatus), w którym Joachim „,przypisywał Bogu nie trójcę, ale czwórcę, czyli trzy Osoby i tę ich wspólną istotę jako czwartą"39.

Choć traktat się nie zachował, co wydaje się zrozumiałe, jeśli weźmiemy pod uwagę jego potępioną przez sobór zawartość, to jednak Joachim atakuje ujęcie Piotra Lombarda także w innych swoich dziełach, a zwłaszcza w medytacji nad znaczeniem zakonnego oficjum z komentarza do Reguły św. Benedykta, w której Magister sententiarum zostaje wymieniony po imieniu ${ }^{40}$. W odróżnieniu od „bezbożności” (impietas) Sabeliusza i „błędu” (pravitas) Ariusza, Joachim określa trynitarne ujęcia Piotra Lombarda mianem „bluźnierstwa” (blasphemia) lub ,przewrotności” (perfidia) ${ }^{41}$. Warto w tym miejscu zauważyć, że Joachim nie był jedynym, który określał nauczanie paryskich mistrzów mianem „bluźnierstwa”. Tego samego słowa użył, opisując uprawianą w tym czasie w Paryżu trynitologię, współczesny opatowi z Fiore prawnik i biskup Stefan z Tournai (1128-1203) ${ }^{42}$.

Konflikt Joachima z Fiore i Piotra Lombarda na płaszczyźnie doktryny trynitarnej jest jednym z najbardziej złożonych problemów, jakie pojawiają się w interpretacji Joachimowej spuścizny. Z pewnością Magister sententiarum nie miał zamiaru wprowadzać rzeczywistej różnicy pomiędzy Boską istotą i Osobami Trójcy Świętej, choć wyrażenie ,jakaś najwyższa rzeczywistość” (una et summa quaedam res), użyte na oznaczenie Boskiej istoty (divina

39 Zob. tamże.

40 „Deinde inter duo nocturna leguntur in hyeme tres lectiones cum responsoriis suis, in estate una tantum cum responsorio suo, quia, sicut iam alibi scripsisse me recolo, in hoc communi tempore, quod agitur inter duo nocturna, oportet aperiri occulta et archana misteria, ut, qualiter credendus sit Deus omnipotens trinus et unus, per ea, que in tribus statibus scripta sunt et scribi oportet, non iam in enigmate, ut in preteritis seculis, sed veluti facie ad faciem intelligatur, abolita primo impietate Sabelli, qui personas negavit, secundo pravitate Arrii, qui unitatem scidit, tertio blasphemia Petri, qui unitatem a Trinitate dividens quaternitatem inducit" - Ioachim Abbas Florensis, Tractatus in expositionem vite et regule beati Benedicti, III, 2, red. A. Patschovsky, Fonti per la storia dell'Italia medievale. Antiquitates, 29, Roma 2008, s. 208; por. tenże, Psalterium decem cordarum, I, I, s. 20; tamże, II, VI, s. 341.

${ }^{41}$ Oprócz Psalterium, I, I, słowo perfidia pojawia się w drezdeńskim rękopisie Liber Figurarum, choć imię Piotra Lombarda również w nim nie występuje. Powodów tego stanu rzeczy należy najprawdopodobniej szukać w postawie kopistów, mających na uwadze soborowe potępienie tego fragmentu Joachimowej spuścizny - zob. K.V. Selge, Einleitung, w: Joachim von Fiore, Psalterium decem cordarum, s. CXLVI; M. Reeves, B. Hirsch-Reich, The Figurae of Joachim of Fiore, S. 103, 212-223; R.E. Lerner, Joachim and the Scholastics, s. 260, przypis 11. Z podobną sytuacją mamy do czynienia w przypadku pochodzącego z pierwszej połowy XIII wieku padewskiego rękopisu przywołanego wyżej Tractatus in expositionem vite et regule beati Benedicti, gdzie wyrażenie „blasphemia Petri” zostało zastąpione przez „blasphemia illorum” - zob. L.E. Lerner, Joachim and the Scholastics, s. 260, przypis 10.

42 Zob. tamże, s. 259, przypis 4. 
essentia), mogło skłaniać do pójścia w tym kierunku ${ }^{43}$. Nie należy zapominać, że w XII wieku Piotr Lombard dopiero zdobywał właściwe sobie miejsce $\mathrm{w}$ teologii, a Joachim z Fiore nie był jedynym, który podał w wątpliwość jego ujęcia; w latach sześćdziesiątych jego doktryna trynitarna została zakwestionowana przez Ryszarda od św. Wiktora, a papież Aleksander III miał zamiar potępić jego opinie chrystologiczne. Przywoływanego już wielokrotnie Bernarda z Clairvaux również niepokoiło wprowadzanie do Trójcy Świętej czwartego elementu, jakie dostrzegał u Gilberta de la Porrée ${ }^{44}$. Ostatecznie, abstrahując od niekorzystnego dla opata splotu późniejszych czynników zewnętrznych, czyli pontyfikatu Innocentego III, którego formacja teologiczna związana była ściśle ze środowiskiem paryskim, można stwierdzić za Tomaszem z Akwinu, że Joachim z Fiore, „nieumiejętnie podchodzący do subtelności prawd wiary", nie zrozumiał do końca Piotra Lombarda, przypisując mu herezję trynitarną, porównywalną z sabelianizmem i arianizmem ${ }^{45}$. Jak twierdzi Bernard McGinn, reakcję Joachima z Fiore można uznać za przejaw protestu przeciw nowej formie uprawiania teologii: ,_...] opat uważał, że teologia Lombarda groziła wyeliminowaniem dynamicznego udziału trzech Osób Boskich w historii świętej, zamykając Trójcę w strukturze abstrakcyjnej terminologii i niebezpiecznych rozróżnieniach" ${ }^{\text {"6 }}$.

\section{Historia Lota i jej duchowe przesłanie}

Sam Joachim z Fiore wyznaje, że wydobycie na światło dzienne tajemnic, jakie kryje w sobie biblijna historia Lota, nie tylko wiele wnosi do jego refleksji nad sensem dziejów, zarysowanej w pięciu księgach Concordia Novi ac Veteris Testamenti, lecz także pozwala każdemu poczuć, ile radości niesie ze sobą ucieczka od spraw świata, a zarazem, ile niepokoju doświadcza człowiek,

${ }^{43}$ Więcej na ten temat - zob. B. McGinn, L'abate calabrese. Gioacchino da Fiore nella storia del pensiero occidentale, Opere di Gioacchino da Fiore: strumenti, 2, Genova 1990, s. 180-182.

44 Zob. tamże.

45 ,Ioachim autem abbas Florensis monasterii non bene capiens verba Magistri praedicti, utpote in subtilibus fidei dogmatibus rudis, praedictam Magistri Petri doctrinam haereticam reputavit, imponens ei quod quaternitatem induceret in divinis, ponens tres personas et communem essentiam, quam credebat sic poni a Magistro Petro quasi aliquid distinctum a tribus personis, ut sic possit dici quasi quartum" - Sancti Thomae de Aquino Expositio super primam et secundam Decretalem ad archidiaconum Tudertinum, 2, http:/www.corpusthomisticum.org/o2d.html [dostęp: 27.02.2019]; por. tenże, Sprostowanie błędów greckich, I, 4, tłum. J. Salij, w: tenże, Dzieła wybrane, red. J. Salij, Kęty 1999, s. 270-272; zob. B. McGinn, L'abate calabrese, s. 221-226; J. Grzeszczak, Chwila jest bliska. Wizje końca w literaturze profetycznej (XII-XX wiek), Biblioteka Filozofii Chrześcijańskiej, 3, Poznań 2001, s. 152-175.

46 B. McGinn, L'abate calabrese, s. 181-182. Na temat debaty historyków i teologów o konsekwencjach, jakie niesie ze sobą przyjęcie stanowiska Akwinaty - zob. tamże, s. 225. 
którego serce jest $\mathrm{w}$ nich pogrążone ${ }^{47}$. Lot pojawia się $\mathrm{w}$ dwunastym rozdziale Księgi Rodzaju jako bratanek Abrama, który wyruszył wraz z nim z Charanu, idąc do kraju ukazanego stryjowi przez Pana. Ich wspólna wędrówka do Kanaanu zakończyła się rozstaniem, będącym wynikiem umowy, na mocy której wspaniałomyślny Abram pozwolił bratankowi wybrać bardziej urodzajną dolinę Jordanu, na której ten ostatni rozbił swe namioty „aż do Sodomy”"48.

Nazywając Lota „sprawiedliwym” (iustus Loth), Joachim z Fiore nie odbiega od ugruntowanej tradycji, wspólnej judaizmowi, chrześcijaństwu $\mathrm{i}$ islamowi. W tych trzech religiach postać ta miała zawsze wydźwięk jak najbardziej pozytywny ${ }^{49}$. Do jego sprawiedliwości, której przejawem była moralna prawość, nawiązuje św. Piotr, pisząc, że Bóg „wyrwał sprawiedliwego Lota, który uginał się pod ciężarem rozpustnego postępowania ludzi nie liczących się z Bożym prawem - sprawiedliwy bowiem mieszkając wśród nich z dnia na dzień duszę swą sprawiedliwą miał umęczoną przeciwnymi Prawu czynami, które widział i o których słyszał"50.

Charakterystyczną dla metody opata interpretację historii Lota znajdziemy w piątej księdze Concordia Novi ac Veteris Testamenti. Joachim z Fiore zastosował $\mathrm{w}$ niej narzędzia hermeneutyczne, zaprezentowane w księgach I-IV i skupione symbolicznie wokół przywołanych wyżej „,czterech istot żyjących” z Ezechielowej wizji oraz czterech „Zwierząt” z Janowej Apokalipsy ${ }^{51}$. Dla Joachima $\mathrm{z}$ Fiore, żyjącego w dynamicznym kontekście religijnym i politycznym, umiejętność odczytania sensu bieżących wydarzeń wymagała uprzedniego znalezienia pewnych punktów oparcia. W jednym ze swoich mniejszych objętościowo dzieł, Enchiridion super Apocalypsim, opat dzieli się z czytelnikiem następującym wyznaniem:

Jako że niewiele pozostało czasu do wyznaczonego momentu otrzymania tego zrozumienia, które w pełni zrealizuje się w Duchu Świętym, a do nas raczej należy

${ }^{47}$ „Sed quia multum pertinet ad rem misterium Loth, scribenda sunt per ordinem verba historie, ut, dum spiritaliter fuerint a nobis discussa, sentiat unusquisque, quanti gaudii sit reliquisse mundum et quante trepidationis adhuc in seculo corde manere" - Joachim von Fiore, Concordia Novi ac Veteris Testamenti, V, 2, 4, 9, s. 619 .

${ }^{48}$ Zob. Rdz 13, 8-12.

${ }_{49}$ Zob. Joachim von Fiore, Concordia Novi ac Veteris Testamenti, V, 2, 4, 15, s. 624; por. tamże, V, 2, 4, 19, s. 626. „Sprawiedliwy” Lot pojawia się często w tradycji żydowskiej, a w Koranie jawi się on jako szczególnie umiłowany przez Boga: „Uratowaliśmy jego [Abrahama - J.G.] i Lota, wprowadzając ich do ziemi, którą pobłogosławiliśmy dla światów [...] A Lotowi daliśmy mądrość i wiedzę i uratowaliśmy go z miasta, które popełniało szpetne czyny; byli oni bowiem ludźmi zła, szerzącymi zgorszenie! I wprowadziliśmy go do Naszego miłosierdzia. Zaprawdę, on był z liczby sprawiedliwych!” - Koran, sura XXI (Prorocy), 71-76, tłum. J. Bielawski, Warszawa 2015, s. 392.

${ }_{50} 2$ P 2,7-8; por. Listy katolickie. Wstęp-przeklad z oryginalu - komentarz, oprac. F. Gryglewicz, Poznań 1959, s. 289.

${ }^{51}$ Zob. przypis 20. 
- jak ukazaliśmy, z Bożego przyzwolenia, w księdze Concordia - zadanie wskazania na zgodność dzieł mających miejsce w nowym przymierzu z dziełami pierwszego, stąd też uznałem za godne uwagi, by te same wydarzenia, które umieściliśmy w relacji do wydarzeń przeszłych drogą zwykłego stwierdzenia, zostały zaczerpnięte z Apokalipsy, ponieważ wydarzenia składające się na historię Kościoła są mniej [niż Apokalipsa - J.G.] godne wiary (minus authenticae judicantur) ${ }^{52}$.

Ten na pierwszy rzut oka dość skomplikowany wywód na temat Joachimowego komentarza Janowej Apokalipsy zawiera ogólną zasadę, która od samego początku przyświeca opatowi: kluczem do zrozumienia dziejowych procesów są verba authentica, czyli teksty prawdziwe i godne zaufania, ponieważ należące do kanonu Pism natchnionych ${ }^{53}$. Ten fundament może stanowić - zdaniem Joachima - pewny punkt wyjścia do dalszych rozważań na temat sensu dziejów. Joachimowa concordia stanowi natomiast rodzaj schematu interpretacyjnego, a sam opat określa ją mianem ,„podobieństwa równych proporcji Nowego i Starego Testamentu" "54. Podobieństwo (similitudo) czy zgodność (consonantia) dwóch Testamentów osadzone są przez Joachima w symbolice biblijnej. Dwa Testamenty są „zwrócone jeden ku drugiemu”, jak twarze cherubów na końcach przebłagalni (Wj 25,20), które w literaturze patrystycznej nabierają duchowych znaczeń, wskazując na pełnię mądrości, a sam Joachim widzi w nich symbol kontemplacji ${ }^{55}$.

Pomijając w tym momencie szczegółową analizę charakterystycznej dla Joachima złożonej teorii sensów biblijnych ${ }^{56}$, należy stwierdzić, że ukazana

52 Ioachim Abbas Florensis, Enchiridion super Apocalypsim, 1245-1252, w: Gioacchino da Fiore sull'Apocalisse. Traduzione e cura di Andrea Tagliapietra. Testo originale a fronte, Milano 1994, s. 222.

${ }^{53}$ Por. G. Constable, dz. cyt., s. 16; J. Grzeszczak, Chwila jest bliska, s. 45. Joachim zdecydowanie odrzuca jako zbędne (superflua) i obce (peregrina) popularne w średniowieczu traktaty i przepowiednie na temat czasu i okoliczności pojawienia się Antychrysta oraz nadejścia końca świata: „Melius est enim salva fide opinioni cedere, ubi certitudo non est, quam diffinire aliquid pertinaciter, quod neque rationi neque auctoritati consentit. Sola ergo que in divinis scripta sunt voluminibus perstringentes et ex eis, que clara sunt, in auctoritate sumentes, superflua illa, que de ortu et operibus Antichristi ac fine mundi ex apocrifis, ut dictum est sumpta libellis a plerisque simplicium amplectantur, velut peregrina et extranea confutamus" - Joachim von Fiore, Concordia Novi ac Veteris Testamenti, Praefatio, 7, s. 11.

${ }^{54}$ „Concordiam proprie esse dicimus similitudinem eque proportionis Novi ac Veteris Testamenti. «Eque» dico quoad numerum, non quoad dignitatem, cum videlicet persona et persona, ordo et ordo, bellum et bellum ex parilitate quadam mutuis se vultibus intuentur, utpote Abraham et $\mathrm{Za}$ charias, Sara et Helisabeth, Ysaac et Iohannes Baptista, Iacob et homo Christus Iesus, duodecim patriarche et numeri eiusdem apostoli et si quod simile" - Joachim von Fiore, Concordia Novi ac Veteris Testamenti, II, 1, 2, 1, s. 65.

55 Zob. tamże, Praefatio, 7, s. 10.

${ }^{56} \mathrm{Na}$ ten temat - zob. J. Grzeszczak, Joachim z Fiore. Średniowieczny przyczynek do teologii dziejów, Studia i Materiały, 87, Poznań 2006, s. 71-90. 
wyżej concordia przynależy do sensu dosłownego, czyli litery, i jako taka stanowi punkt wyjścia długiej drogi, prowadzącej do sensu duchowego (spiritalis intellectus). Przewodnikiem na tej drodze jest Duch Święty i wiedzie ona - według Joachima - przez dzieje, a ostatnia epoka, pozostająca pod szczególnym patronatem trzeciej Osoby Trójcy Świętej, przyniesie ludziom obfite owoce duchowego zrozumienia (intelligentia spiritualis). W piątej księdze Concordia Novi ac Veteris Testamenti Joachim analizuje kilka epizodów starotestamentalnych, a wśród nich historię Lota, mając nadzieję, że ich interpretacja pozwoli na dotarcie do szeregu szczegółów tego, co nastąpi w czasach ostatecznych ${ }^{57}$. Wśród tych szczegółów można się również doszukać XII-wiecznej teologii spekulatywnej.

Bogatsi o nakreślone wyżej podstawowe elementy Joachimowej metody, przystępujemy teraz do analizy historii Lota $w$ interpretacji opata z Fiore. Bratanek Abrahama pojawia się w piątej księdze Joachimowego traktatu, w drugim epizodzie starotestamentalnym, czyli $\mathrm{w}$ historii Abrahama ${ }^{58}$. Widzimy go najpierw, jak rozstaje się ze swoim stryjem, by zamieszkać na równinie w sąsiedztwie Sodomy, co nie pozostaje bez znaczenia dla duchowej wymowy jego perypetii, ukrytej pod zasłoną litery. Joachim zauważa, że Abraham zamieszkał na wyżynie (in montanis), natomiast Lot w głębokiej dolinie (in planitie profunde vallis), która przed zniszczeniem Sodomy była ,jak ogród Pana, jak ziemia egipska"59. Przewaga, jaką uzyskał w ten sposób nad swoim stryjem, była jednak pozorna, ponieważ - jak podkreśla opat z Fiore - to do Abrahama sam Bóg jeden w trzech Osobach (unus et trinus) przychodził $\mathrm{w}$ gościnę i dzielił się, jak z przyjacielem, swoimi myślami i zamiarami ${ }^{60}$. Konkluduje Joachim: „To, co zostało objawione Abrahamowi, który mieszkał w górach, nie zostało objawione Lotowi, mieszkającemu na dole"61. Opat podąża dalej tym tropem i zauważa, że Bóg zstąpił na dwóch aniołów i przyszedł do Sodomy wieczorną porą (hora vespertina), aby „,wszyscy poznali, że nie należy sądzić «przedwcześnie, dopóki nie przyjdzie Pan»" ${ }^{62}$. Hora vespertina to czasy ostateczne, a widoczne w Joachimowym wywodzie przejście do zagadnień moralnych i przywołanie porażenia ślepotą rozpustnych

${ }^{57}$ „In quinto libro agitur de precipuis historiis Prioris Testamenti, qualiter intelligende sint secundum spiritalem intellectum, eo quod ex fine ipsarum historiarum ostendantur nobis multa que futura sunt in novissimis diebus, si eas spiritaliter intelligimus" - Joachim von Fiore, Concordia Novi ac Veteris Testamenti, Praefatio, 11, s. 15; por. Iz 2,2; Dn 10,14; Dz 2,17; 2 Tm 3,1; 2 P 3,3.

${ }^{58}$ Zob. Joachim von Fiore, Concordia Novi ac Veteris Testamenti, V, 2, 4-6, s. 612-650.

${ }^{59}$ Zob. tamże, V, 2, 4, 1, s. 613; Rdz 13,10.

${ }^{60}$ Zob. Concordia Novi ac Veteris Testamenti, V, 2, 4, 2, s. 614; Rdz 18,17-19.

${ }^{61}$ Joachim von Fiore, Concordia Novi ac Veteris Testamenti.

${ }^{62}$ Zob. tamże; 1 Kor 4,5. 
mieszkańców Sodomy zawiera ostrzeżenie przed karą, jaką może wymierzyć na końcu Ten, który oddaje każdemu według jego czynów ${ }^{63}$.

Sprawiedliwość Lota, rozważającego słowo Boga w swoim sercu, uczyniła go wygnańcem i obcym w oczach synów tego świata, choć to Abraham i jego potomstwo zdołają „uciec przed łukiem”, chroniąc się na górę kontemplacji (mons contemplationis) ${ }^{64}$. Nie oznacza to jednak, że pozostali, mieszkający w miastach, będą pozbawieni pomocy:

Ci zaś, którzy - jak Lot - pozostają w Sodomach, nie będą zgoła mogli poznać czasu [ostatecznych wydarzeń - J.G.], jak tylko poprzez przychodzących aniołów, to jest kaznodziejów prawdy, którzy zstąpią do nich, poruszeni miłosierdziem, i w ten sposób zdołają wyrwać niektórych spośród skazanych na zatracenie i wybawić „,w dniu złym” od upadku, jaki stanie się udziałem wielu ${ }^{65}$.

Sodoma jest synonimem siedliska seksualnej perwersji i jako taka nadaje kierunek Joachimowej egzegezie dziejów Lota. Jeśli dodać do tego góry jako duchową antytezę dolin, to $\mathrm{w}$ rozważaniach opata $\mathrm{z}$ Fiore miasto położone na równinie jawi się jako środowisko, w którym panuje duch tego świata, daleki od upragnionego ideału. Joachim zaznacza, że okres pomiędzy epoką Syna i Ducha Świętego przyniesie postępujący upadek wiary i moralności. Przywołani wyżej „kaznodzieje prawdy” (predicatores veritatis) zwrócą się do ludzi w bezpośredniej bliskości dnia sądu z wezwaniem do nawrócenia ${ }^{66}$. W komentarzu Janowej Apokalipsy opata z Fiore ogarnia zachwyt, gdy pisze o ,potężnym aniele, zstępującym z nieba, obleczonym w obłok" ${ }^{67}$. Nazywa go „kaznodzieją prawdy", umieszcza w kontekście końca świata i wiąże ściśle z trzecią Osobą Trójcy Świętej. Predicator veritatis wystąpi w „dniach złych” (por. Ef

63 "Igitur, cum pervenissent ANGELI SODOMAM et iniuriam ab incolis recepissent, eduxerunt inde Loth, qui et receperat eos. Ceteri autem cum suis urbibus veluti in ictu oculi terribiliter sunt puniti, ut omnes, qui hoc audirent, scirent, quod Altissimus regnaret in celis, qui posset reddere unicuique secundum opera sua" - Joachim von Fiore, Concordia Novi ac Veteris Testamenti, s. 614-615; zob. Rdz 19,11; Ps 62,13; Rz 2,6.

${ }^{64}$ Por. Ps 60,6. Ucieczka w góry, o której mowa w Mt 24,16, odnosi się nie tylko do realiów palestyńskich, ponieważ Juda symbolizuje całą ziemię, będącą mieszkaniem nowego Ludu Bożego, a nie tylko okolice Jerozolimy, w których mieszkali chrześcijanie nawróceni z judaizmu. Jezus zapowiada również, że prześladowania wiernych Bogu będą podobne do tych, którym Żydzi zostali poddani w czasach machabejskich - zob. 1 Mch 2,28; por. 1,53; 2,29-30; por. Ewangelia wedtug św. Mateusza. Wstęp-przekład z oryginału-komentarz, red. J. Homerski, Poznań-Warszawa 1979, s. 313.

65 Joachim von Fiore, Concordia Novi ac Veteris Testamenti, V, 2, 4, 6, s. 617-618; por. Rdz 18,21-22; 19,1; Ef 6,13.

66 Zob. Joachim von Fiore, Concordia Novi ac Veteris Testamenti, V, 2, 9, 10, s. 694; V, 2, 9 , 14, s. 698.

67 Zob. Expositio magni prophete Abbatis Ioachim in Apocalipsim, f. 137ra-138va; Ap 10,1-2. 
5,16), opuści wyżyny kontemplacji, by nauczyć ludzi, jak pogardzać rzeczami ziemskimi i miłować niebieskie (terrena despicere et amare celestia) ${ }^{68}$.

W Joachimowej interpretacji dziejów Lota ważną rolę odgrywają też tzw. „mężowie duchowi” (viri spiritales), którzy - jak Abraham za mieszkańcami Sodomy - będą się wstawiać za grzesznym ludem ${ }^{69}$. Jako że w Sodomie nie znaleziono nawet dziesięciu sprawiedliwych, w tym przypadku biblijną „Resztą”, którą Bóg ocali od zagłady, stał się $\operatorname{Lot}^{70}$. Przed końcem świata odpowiednikiem Lota będą prawi ludzie, świeccy i duchowni, zajęci sprawami doczesnymi i nienawidzący czynów ludzi przewrotnych, choć z racji podejmowanych zadań zmuszeni do pozostawania wraz z nimi ${ }^{71}$. Rozbudowana Joachimowa egzegeza widzi w dwóch aniołach, którzy przybyli wieczorem do Sodomy (por. Rdz 19,1), dwie grupy duchowych mężów (duo genera spiritalium virorum), których symbolem są Mojżesz i Eliasz: działanie pierwszego ograniczało się do prowadzenia duchowego ludu (populus spiritalis) przez pustynię; drugi wiódł żywot pustelnika i przez to stał się protoplastą życia mniszego. Idąc dalej, pierwszy anioł wskazuje na Syna Bożego, który przyszedł na świat w ciele; drugi - na Ducha Świętego, objawiającego się pod postacią gołębicy, w szumie gwałtownego wiatru i pod postacią ognia ${ }^{72}$. Nie bez znaczenia jest też pora dnia: viri spiritales pojawią się na ziemi „pod wieczór tego świata" (ad vesperum huius seculi) i będą przynaglać bojących się Boga do wyjścia spośród grzeszników, tak jak o świcie dnia Bożej kary dwaj aniołowie przynaglali Lota do opuszczenia skazanej na zagładę Sodomy ${ }^{73}$. „Biada zaś tym, którzy nie posłuchają ich słów!” - ostrzega Joachim z Fiore ${ }^{74}$.

Opat z Fiore jest przekonany, że tajemnica Lota (mysterium Loth) niesie w sobie wielkie bogactwo treści, kształtujących zwłaszcza właściwą naszemu autorowi apokaliptyczną duchowość ${ }^{75}$. Szczegółową ich analizę rozpoczyna od

68 Zob. Expositio magni prophete Abbatis Ioachim in Apocalipsim, f. 137ra-138va. Więcej na temat apokaliptycznej wymowy „kaznodziei prawdy” - zob. J. Grzeszczak, Joachim z Fiore, s. 131.

69 „Rogat quoque Dominum Abraham pro civitate Sodomorum, quia viri spirtales rogant Dominum pro populo peccatore, ut saltim pro pietate iustorum indulgentiam mereatur" - Joachim von Fiore, Concordia Novi ac Veteris Testamenti, V, 2, 4, 6, s. 618; por. Rdz 18,23-32.

${ }_{70}$ Zob. Joachim von Fiore, Concordia Novi ac Veteris Testamenti, V, 2, 4, 6, s. 618; por. Iz 10,20$-23 ; \mathrm{Rz} 9,27$.

71 „Queris, qui sunt illi? Boni coniugati et boni clerici impliciti curis mundi, qui abhorrent quidem scelera impiorum, sed tamen ab illorum participatione abstinere nequeunt, quamdiu cum illis manent in societate comuni" - Joachim von Fiore, Concordia Novi ac Veteris Testamenti, V, 2, 4, 7 , s. 618 .

72 Zob. tamże, V, 2, 4, 8, s. 618-619; por. tamże, II, 2, 5, 2, s. 164.

73 Zob. tamże, V, 2, 4, 8, s. 618-619; Rdz 19, 15; por. Iz 48,20; 52,11; Jr 50,8; 51,45; Ap 18,4.

74 Zob. Joachim von Fiore, Concordia Novi ac Veteris Testamenti, V, 2, 4, 8, s. 619.

75 Zob. przypis 45. Na temat apokaliptycznej duchowości w wydaniu Joachima z Fiore - zob. B. McGinn, Apocalyptic Spirituality. Treatises and Letters of Lactantius, Adso of Montier-en-Der, Joachim of Fiore, the Franciscan Spirituals, Savonarola, London 1980, s. 97-148; tenże, Visions of 
przywołania in extenso tekstu Rdz 19,1-17, by przystąpić następnie do wydobywania na światło dzienne ukrytych w nim znaczeń. Czynność tę porównuje do śpiewania żałobnej pieśni (lugubre carmen) ${ }^{76}$. Przywołajmy tylko niektóre fragmenty Joachimowego wywodu.

„Zanim jeszcze udali się na spoczynek, mieszkający w Sodomie mężczyźni, młodzi i starzy, ze wszystkich stron miasta, otoczyli dom, wywołali Lota i rzekli do niego «Gdzie tu są ci ludzie, którzy przyszli do ciebie tego wieczoru? Wyprowadź ich do nas, abyśmy mogli z nimi poswawolić!»" "77. Joachimowa intelligentia spiritualis tego biblijnego tekstu oddala się diametralnie od jego litery: zanim mężowie Boży spoczną w sercach wydających owoc słuchaczy, którym głoszą słowo życia, pojawiają się niegodziwcy, którzy chcą, by „ludzie nazywali ich Rabbi”, i domagają się, by prowadzono z nimi dysputy za pomocą językowych kruczków (in astutia lingue), aby tym sposobem „bezcześcić udręczonych i upokorzonych słuchaczy nieczystym nasieniem swoich złych rozmów"78. Opat z Fiore nie wymienia nikogo z imienia, lecz zauważa, że ci „synowie tego świata” są zawsze gotowi bardziej do dyskutowania niż do słuchania, co więcej, nie chcą słuchać o zbliżającej się zagładzie, aby zostali zbawieni, lecz pragną jedynie zwyciężać orężem swojego słowa, które jest rozpustne, jak czyny mieszkańców Sodomy ${ }^{79}$. Wzorem Lota, który zamknął drzwi, aby uchronić aniołów przed krzywdą, należy - zdaniem Joachima z Fiore - chronić skromnych mężów Bożych przed „niszczycielami prawdy" (corruptores veritatis) ${ }^{80}$.

Kim są simplices et ydiote, których, podobnie jak córki Lota mężczyznom z Sodomy, można wydać ludziom rozmiłowanym w dysputach ${ }^{81}$ ? Wcześniej, komentując Rdz 1,24-28, Joachim z Fiore zastanawia się nad duchową wymową rozmaitych zwierząt i zauważa, że choć ptactwo powietrzne z natury przebywa wyżej niż ryby morskie i „zwierzęta pełzające po ziemi”, to i te ostatnie nie są pozbawione pozytywnych znaczeń (bona significatio), a jako przykład podaje owce, woły i inne zwierzęta składane w ofierze, a także osły i wielbłądy, które pokornie dźwigają ciężary ich panów, ponieważ - jak zaznacza Joachim, przywołując psalmy 113 i 138 - Bóg „,W dół spogląda na niebo

the End. Apocalyptic Traditions in the Middle Ages, New York 1998, s. 126-141; J. Grzeszczak, Czy Joachim z Fiore byt mistykiem?, s. 63-67.

${ }^{76}$ Zob. Joachim von Fiore, Concordia Novi ac Veteris Testamenti, V, 2, 4, 10, s. 619-621.

77 Rdz 19,4-5.

${ }^{78}$ Joachim von Fiore, Concordia Novi ac Veteris Testamenti, V, 2, 4, 14, s. 623; por. J 6,69; Ef 5,26; $1 \mathrm{~J} 1,1 ;$ Mt 23,7-8.

${ }_{79}$ Zob. Joachim von Fiore, Concordia Novi ac Veteris Testamenti, V, 2, 4, 14, s. 623; por. Łk 16,8 .

${ }^{80}$ Zob. Joachim von Fiore, Concordia Novi ac Veteris Testamenti, V, 2, 4, 14, s. 623.

${ }^{81}$ Zob. przypis 2. 
i na ziemię" i ,patrzy łaskawie na pokornego"82. Zwierzęta lądowe oznaczają ludzi pokornych, spokojnych i tych, którzy z drżeniem czczą słowo Boże ${ }^{83}$. Tak jak zwierzęta boją się rózgi ich panów, tak też ludzie, o których tu mowa, zawdzięczają swoje cechy Bożej bojaźni; a jak istnieje ogromne zróżnicowanie w świecie zwierząt, tak też - stwierdza Joachim - wśród ludzi mamy do czynienia zarówno z mądrymi i roztropnymi, jak i prostymi i niewykształconymi (simplices et ydiote); wystarczy jednak, by wierzyli w Boga i żyli w Bożej bojaźni, a nie zostaną wyłączeni z grona wybranych ${ }^{84}$.

W literaturze średniowiecznej simplices et idiotae oznaczają świeckich, choć, jak twierdzi Giles Constable, „techniczny słownik pojęć średniowiecznego życia religijnego jest skomplikowany i niejednoznaczny", a w XII wieku zasób terminów wzbogaca się o kolejne określenia ${ }^{85}$. Generalnie w średniowieczu simplex et idiota to inaczej świecki (laicus), w odróżnieniu od clericus, czyli osoby wykształconej, w domyśle duchownego, choć zróżnicowany poziom wykształcenia ówczesnych duchownych nie pozwala w tym przypadku na zbyt łatwe uogólnienia ${ }^{86}$.

$\mathrm{W}$ interesującym nas fragmencie Joachim odchodzi od przyjętych w XII wieku rozróżnień i przeciwstawia świeckich mężom duchowym (viri spiritales). Kluczem do zrozumienia jego myśli jest występujące w tekście słowo conversatio $^{87}$. Należy ono do słownika terminów średniowiecznej duchowości i odnosi się nie tyle do pobożności, ile raczej do jedności wyznawanej wiary i działania, biorącej początek z przeżytego nawrócenia ${ }^{88}$. W przypadku Joachimowych duchowych mężów conversatio oznacza prowadzenie przez nich już

82 „Notandum quia, quod distat inter VOLATILIA et PISCES MARIS, hoc distat inter PISCES MARIS et BESTIAS TERRE, quia TERRA inferius elementum est et pertinet ad illos, qui bruti sunt corde, et de hiis, que Dei sunt, nichil pertinet ad eos. Verumtamen quia humilia respicit Deus, non deest bona significatio in quibusdam animalibus terre, maxime in illis, que accepta fiebant in sacrificio, sicut sunt oves et boves et hiis similia. Sed et asini et cameli in bonam possunt recipi significationem, quia portant onera dominorum suorum" - Joachim von Fiore, Concordia Novi ac Veteris Testamenti, V, 1, 7, 2, s. 532 ; por. Ps 113,$6 ; 138,6$.

${ }_{83}$ Por. Iz 66,2.

${ }^{84}$ Joachim von Fiore, Concordia Novi ac Veteris Testamenti, V, 1, 7, 3, s. 533; por. Mt 11,25; Łk 10,21.

${ }^{85}$ Zob. G. Constable, dz. cyt., s. 9-10.

${ }^{86}$ Zob. tamże.

${ }^{87}$ „Viros autem spiritales, quorum conversatio in celis est, in pace dimittite et quiete [...]”- Joachim von Fiore, Concordia Novi ac Veteris Testamenti, V, 2, 4, 15, s. 624; por. Flp 3,20.

${ }^{88}$ W Regule św. Benedykta mowa o anachoretach i eremitach, rekrutujących się spośród mnichów, którzy, nie pod wpływem młodzieńczej gorliwości nowicjusza (non conversationis fervore novicio), lecz po długim okresie duchowego dojrzewania w klasztornej wspólnocie, są gotowi do prowadzenia duchowej walki w samotności eremu. Święty Benedykt posługuje się też zwrotem miserrima conversatio na określenie sposobu życia, jaki prowadzą wędrowni mnisi (genus gyrovagum), którzy krążą od klasztoru do klasztoru, szukając gościnności, dobrego jedzenia i realizacji swoich upodobań. Jak dodaje, lepiej byłoby pominąc ten przypadek milczeniem: „De quorum omnium ho- 
tu na ziemi życia właściwego ojczyźnie niebieskiej, a więc oddanego kontemplacji i duchowemu zrozumieniu (intelligentia spiritualis).

O tym, że sodomici, którzy oblegli dom Lota, wskazują na XII-wiecznych dialektyków, przekonują nas aluzje do używanej przez nich terminologii oraz intelektualnej pychy, która popycha ich do autorytatywnego wypowiadania się na temat rzeczy boskich ${ }^{89}$. Nieco dalej Joachim porównuje ich do uczonych w Prawie, którzy wzięli „klucze poznania”, ale sami nie weszli do królestwa Bożego i innym nie pozwolili wejśćc ${ }^{90}$. Zamiast otwierać wiarą drzwi duchowego zrozumienia (intelligentia spiritualis), które znajduje się w sercach wybranych, wyważają je, posługując się ludzkim rozumem (humana ratione) i prowadząc dysputy (disputatione verborum) nad słowami Boga, wypowiadanymi przez mężów duchowych ${ }^{91}$.

„Wtedy ci dwaj mężowie, wysunąwszy ręce, przyciągnęli Lota ku sobie do wnętrza domu i zaryglowali drzwi. Tych zaś mężczyzn u drzwi domu, młodych i starych, porazili ślepotą. Toteż na próżno usiłowali oni odnaleźć wejście"92. Joachim z Fiore uważa, że kalectwo, jakim zostali dotknięci sodomici, jest zapowiedzią duchowej ślepoty, która polega na tym, że dotknięci nią, zarówno świeccy, jak i duchowni (a laico usque ad sacerdotem), zatrzymują się na literze, a nie widzą ducha; ich postępowanie przypomina oglądanie okładki księgi, bez wniknięcia w bogactwo zawartej w niej treści ${ }^{93}$. Innym zagrożeniem jest duchowa ociężałość i brak wiary w ostrzeżenia przed nadchodzącą zagładą. Joachim zapowiada zbliżającą się godzinę, w której mężowie duchowi mocą wiary uchronią od śmierci swoich bojących się Boga przyjaciół, podobnie jak aniołowie, którzy chwycili za ręce Lota i jego dwie córki, i siłą wyprowadzili ich poza miasto ${ }^{94}$. Według Joachimowej periodyzacji,

rum miserrima conversatione melius est silere quam loqui" - Regula monasteriorum sancti Benedicti abbatis, 1, Città del Vaticano 2002, s. 31-32; zob. G. Constable, dz. cyt., s. 15.

${ }^{89}$ „Et bene Loth DUAS FILIAS, quas habebat, exposuit, qua secundum practicam, ut aiunt, et theoricam discipulos, qui eos audiant, habere desiderant, ut sibi non solum in carnalibus et humanis, verum etiam in spiritalibus et divinis nomen magisterii arroganter ascribant" - Joachim von Fiore, Concordia Novi ac Veteris Testamenti, V, 2, 4, 15, s. 624-625. Na temat znaczenia pojęć practica et theorica w XII-wiecznej filozofii - zob. tamże, przypis 191. Użyte przez Joachima wyrażenie magisterii nomen pojawia się w teologii Abelarda - zob. P. Abelard, Theologia Christiana, III, 32, red. E.M. Buytaert, w: Petri Abaelardi Opera Theologica, II, Corpus Christianorum. Continuatio Mediaevalis, 12, Turnhout 1969, s. 380-385.

${ }^{90}$ Zob. Joachim von Fiore, Concordia Novi ac Veteris Testamenti, V, 2, 4, 19, s. 626; por. Łk 11,52; Mt 23,13.

${ }^{91}$ Zob. Joachim von Fiore, Concordia Novi ac Veteris Testamenti, V, 2, 4, 19, s. 626.

${ }_{92} \operatorname{Rdz} 9,10-11$.

93, ,[... ] per acceptam a Domino iudicii potestatem ipsos peccatores interna PERCUTIUNT CECITATE, a laico usque ad sacerdotem, ut palpantes litteram non videant spiritum, et sentientes exteriora libri internos apices non percipiant" - Joachim von Fiore, Concordia Novi ac Veteris Testamenti, V, 2, 4, 21, s. 627.

${ }^{94}$ Zob. tamże, V, 2, 4, 22, s. 627; Rdz 19,16. 
wyrwanie Lota i jego najbliższych z Sodomy miało miejsce o świcie dnia zagłady i jest zapowiedzią prześladowań towarzyszących przejściu od drugiej do trzeciej epoki dziejów ${ }^{95}$.

Konkludując rozważania zawarte w tej części artykułu, należy stwierdzić, że Joachimowa interpretacja tajemnicy Lota (mysterium Loth) jest głęboko osadzona w apokaliptyce opata z Fiore. Częścią tej ostatniej jest duchowe zrozumienie (intelligentia spiritualis) - dar Ducha Świętego, który zostanie szczególnie obficie udzielony w trzeciej epoce dziejów, poprzedzającej koniec świata i sąd ostateczny. Dzieje ludzkości są także dziejami oporu wobec duchowego rozumienia, który przejawia się upartym trwaniem przy literze ${ }^{96}$. Mysterium Loth to zapowiedź zmagań pomiędzy literą i duchem, a XII-wieczni dialektycy, których figurą są zdegenerowani mieszkańcy biblijnej Sodomy, przeszkadzają w realizacji dziejowego planu, który Joachim pragnie zrozumieć i ukazać całej ludzkości.

\section{Zakończenie}

Joachim z Fiore należy do grupy XII-wiecznych teologów, odnoszących się nie tylko z rezerwą, ale wręcz krytycznych do dialektyki, która, jako teologia spekulatywna, uczyniła przedmiotem swojego zainteresowania prawdy objawione. Zarówno ta postawa, jak i bliskość ideowa, wynikająca z zakonnej przynależności, sytuują opata z Fiore w kręgu Bernarda z Clairvaux, który uchodzi za wiodącego krytyka XII-wiecznych „filozofów”. Analiza Joachimowej interpretacji historii biblijnego Lota pozwala jednak zauważyć istotne różnice, występujące pomiędzy opatami z Fiore i Clairvaux. Joachimowi z Fiore, który jest przede wszystkim apokaliptykiem, dialektyka średniowiecznych mistrzów jawi się jako przeszkoda w realizacji dziejowego procesu

95 Jako apokaliptyk Joachim z Fiore umieszcza wydarzenia, których jest świadkiem, w obrębie scenariusza, jaki dostarcza Janowa Apokalipsa, a zwłaszcza widoczne w tej księdze następstwo prześladowań, które wyznaczają trąby, czasze i pieczęcie. Wydarzenia, które Joachim zapowiada w Concordia Novi ac Veteris Testamenti, interpretując to, co spotkało biblijnego Lota, nastąpią „o zmierzchu” szóstej ery dziejów i „o świcie” siódmej”, kiedy dokona się przejście od epoki Syna do epoki Ducha Świętego: „Et bene hec compulsio non VESPERE, quando angeli venerunt Sodomam, sed MANE diluculo facta est, quia, qui circa finem huius sexte etatis exhortantur electos Dei, ut deserant mundum et ea, que sunt mundi, eo quod prope sit desolatio eius, circa principium septime, quod prope est, immo quod in aliquibus iam incepit, non iam per exhortationem dicturi sunt aliquid, sed compellent, dicente de hora illa Iohanne in libro Apocalypsis: Omnis servus et liber abscondent se in speluncis et petris montium. Et dicent montibus et petris: "Cadite super nos et abscondite nos a facie sedentis super thronum et ab ira Agni, quoniam venit dies magnus ire ipsorum! Et quis poterit stare?»" - Joachim von Fiore, Concordia Novi ac Veteris Testamenti, V, 2, 4, 22, s. 628; por. 1 Kor 7,31; Iz 13,6; Dn 9,26; J1 2,1; Mt 24,33; Łk 21,31; Ap 1,3; 6,15-16.

96 Więcej na ten temat - zob. J. Grzeszczak, Joachim z Fiore, s. 79-80. 
spirytualizacji Kościoła i świata i jako taka stanowi zagrożenie porównywalne ze średniowiecznymi herezjami. U początku tych ostatnich zwykle znajdziemy ludzką pychę i ślepe przywiązanie do litery Pisma Świętego, a więc te same postawy, które Joachim dostrzega w działalności XII-wiecznych szkół teologicznych. Joachimowa krytyka teologii trynitarnej Piotra Lombarda jest tego wymownym przykładem.

Apokaliptyczna interpretacja historii Lota staje się dla opata z Fiore okazją do zaprezentowania w sposób dosadny i niestroniący od emfazy własnego sprzeciwu wobec XII-wiecznych dialektyków, którzy działają destrukcyjnie, odwracając uwagę od nadchodzącej apokalipsy. Apokaliptyczna duchowość Joachima z Fiore jawi się więc jako podstawowy klucz interpretacyjny, pozwalający zrozumieć nie tylko niechęć opata do dialektyki, ale i jego dystans wobec tego, co niosło ze sobą średniowieczne miasto, które już wkrótce miało odegrać kluczową rolę w ruchu teologicznym, przejmując zadania pozostające dotychczas w gestii klasztorów. Sodoma i jej spektakularna zagłada należą do tych obrazów biblijnych, które niosą ze sobą silny ładunek treści moralnych, i stąd podjęcie tego wątku pozwoliło Joachimowi z Fiore na krytyczne ustosunkowanie się do niektórych XII-wiecznych przejawów życia intelektualnego.

JOACHIM OF FIORE IN THE FACE OF 12TH-CENTURY SPECULATIVE THEOLOGY

\section{SUMMARY}

In one of his main works, Concordia Novi ac Veteris Testamenti, Joachim of Fiore (1135-1202) interprets the story of the biblical Lot, shown in chapter 19 of Genesis. Using in practice the method of compliance (concordia) of the Old and New Testaments and an extensive theory of biblical meanings, he sees in the degenerated inhabitants of Sodom the announcement of medieval dialects. The negative attitude of the Abbot of Fiore (Calabrian Abbot) to speculative theology results from his apocalyptic vision of history, in which the key role is played by spiritual men (viri spiritales), who herald the Holy Spirit era. According to Joachim of Fiore, self-confident and self-based dialectics are destructive, diverting attention from the coming apocalypse. Stuck in a letter, they do not achieve the spiritual understanding (intelligentia spiritualis) of the Bible and prevent others from doing so. The interpretation of Lot's story by Joachim of Fiore reveals the twelfth-century intellectual climate as monastic theology gradually gives way to scholasticism practiced in cities.

Keywords: Joachim of Fiore; Lot; speculative theology 
Stowa kluczowe: Joachim z Fiore; Lot; teologia spekulatywna

\section{BIBLIOGRAFIA}

\section{ŹRÓDŁA}

Augustyn, Wyznania, tłum. Z. Kubiak, Kraków 1997.

Dante Alighieri, Boska Komedia, tłum. A. Świderska, Kęty 1999.

Dokumenty Soborów Powszechnych. Tekst grecki, taciński, polski, t. 2: 869-1312, red. A. Baron, H. Pietras, Kraków 2003.

Expositio magni prophete Abbatis Ioachim in Apocalipsim, Venetiis 1527.

Gioacchino da Fiore, Dialoghi sulla prescienza divina e la predestinazione degli eletti, red. G.L. Potestà, Opere di Gioacchino da Fiore: testi e strumenti, 14, Roma 2001.

Ioachim Abbas Florensis, De articulis fidei ad fratrem Iohannem. Confessio fidei, red. V. De Fraja, Fonti per la storia dell'Italia medievale. Antiquitates, 37, Roma 2012.

Ioachim Abbas Florensis, Enchiridion super Apocalypsim, w: Gioacchino da Fiore sull'Apocalisse. Traduzione e cura di Andrea Tagliapietra. Testo originale a fronte, Milano 1994, s. 127-325.

Ioachim abbas Florensis, Intelligentia super calathis ad abbatem Gafridum, w: Ioachim abbas Florensis, Scripta breviora, red. A. Patschovsky, G.L. Potestà, Fonti per la storia dell'Italia medievale. Antiquitates, 40, Roma 2014, s. 183-217.

Ioachim abbas Florensis, Quaestio de Maria Magdalena et Maria sorore Lazari et Marthae, w: Ioachim abbas Florensis, Scripta breviora, red. A. Patschovsky, G.L. Potestà, Fonti per la storia dell'Italia medievale. Antiquitates, 40, Roma 2014, s. 243-260.

Ioachim abbas Florensis, Tractatus in expositionem vite et regule beati Benedicti cum appendice fragmenti (I) de duobus prophetis in novissimis diebus praedicaturis, red. A. Patschovsky, Fonti per la storia dell'Italia medievale. Antiquitates, 29, Roma 2008.

Ioachim abbas Florensis, Tractatus super quatuor evangelia, red. F. Santi, Fonti per la storia dell'Italia medievale. Antiquitates, 17, Roma 2002.

Joachim von Fiore, Concordia Novi ac Veteris Testamenti, red. A. Patschovsky, t. 2, Monumenta Germaniae Historica. Quellen zur Geistesgeschichte des Mittelalters, 28/3, Wiesbaden 2017.

Joachim von Fiore, Concordia Novi ac Veteris Testamenti, red. A. Patschovsky, t. 3, Monumenta Germaniae Historica. Quellen zur Geistesgeschichte des Mittelalters, 28/2, Wiesbaden 2017.

Joachim von Fiore, Psalterium decem cordarum, red. K.V. Selge, Monumenta Germaniae Historica. Quellen zur Geistesgeschichte des Mittelalters, 20, Hannover 2009.

Koran, thum. J. Bielawski, Warszawa 2015.

Petrus Abaelardus, Theologia Christiana, red. E.M. Buytaert, w: Petri Abaelardi Opera Theologica, II, (Corpus Christianorum. Continuatio Mediaevalis, 12, Turnhout 1969.

Regula monasteriorum sancti Benedicti abbatis, Città del Vaticano 2002.

Sancti Bernardi abbatis clarae-vallensis sermones in Cantica Canticorum, red. H. Hurter, Sanctorum Patrum opuscula selecta ad usum praesertim studiosorum theologiae, series altera, 5, Oeniponte 1888 .

Sancti Thomae de Aquino Expositio super primam et secundam Decretalem ad archidiaconum Tudertinum, http://www.corpusthomisticum.org/o2d.html [dostęp: 27.02.2019].

Tomasz z Akwinu, Sprostowanie błędów greckich, tłum. J. Salij, w: Tomasz z Akwinu, Dzieła wybrane, red. J. Salij, Kęty 1999, s. 265-323.

\section{OPRACOWANIA}

Anitchkof E., Joachim de Flore et les milieux courtois, Roma 1931. 
Balistreri C., La figura di Gioacchino da Fiore nell'opera di D.S. Merežkovskij, w: Gioacchino da Fiore nella cultura contemporanea. Atti del $6^{\circ}$ Congresso internazionale di studi gioachimiti, San Giovanni in Fiore - 23-25 settembre 2004, red. G.L. Potestà, Opere di Gioacchino da Fiore: testi e strumenti, 17, Roma 2005, s. 127-141.

Bronk A., Majdański S., Teologia - próba metodologiczno-epistemologicznej charakterystyki, „Nauka” 2 (2006), s. 81-110.

Constable G., The Reformation of the Twelfth Century, Cambridge 1996.

De Fraja V., Da Gerusalemme a Babilonia. La tipologia della contrapposizione e della decadenza tra XII e XIII secolo, „Rivista di storia del cristianesimo” 1 (2004), s. 39-66.

De Fraja V., Oltre Cîteaux. Gioacchino da Fiore e l'ordine florense, Opere di Gioacchino da Fiore: testi e strumenti, 19, Roma 2006.

Ewangelia wedtug św. Mateusza. Wstęp - przektad z oryginatu - komentarz, oprac. J. Homerski, Poznań-Warszawa 1979.

Grundmann H., Kirchenfreiheit und Kaisermacht um 1190 in der Sicht Joachims von Fiore, „Deutsches Archiv für Erforschung des Mittelalters" 19 (1963), s. 353-396.

Grzeszczak J., Chwila jest bliska. Wizje końca w literaturze profetycznej (XII-XX wiek), Biblioteka Filozofii Chrześcijańskiej, 3, Poznań 2001.

Grzeszczak J., Czy Joachim z Fiore byt mistykiem? Kilka uwag na temat apokaliptycznej duchowości kalabryjskiego opata, „Filozofia Chrześcijańska” 15 (2018), s. 59-81.

Grzeszczak J., Głos teologa w sprawach średniowiecznej polityki. Diagramy Roma i Babilonia oraz ich wymowa doktrynalna i moralna, „Kronos. Metafizyka, Kultura, Religia” 2014, nr 2, s. $122-140$.

Grzeszczak J., Joachim z Fiore. Średniowieczny przyczynek do teologii dziejów, Studia i Materiały, 87, Poznań 2006.

Grzeszczak J., Moralna wymowa gestu namaszczenia stóp i głowy Jezusa w Quaestio de Maria Magdalena et Maria sorore Lazari et Marthae Joachima z Fiore, „Vox Patrum” 69 (2018), s. $175-193$.

Joachim von Fiore, Concordia Novi ac Veteris Testamenti, red. A. Patschovsky, t. 1, Monumenta Germaniae Historica. Quellen zur Geistesgeschichte des Mittelalters, 28/1, Wiesbaden 2017.

Księga Rodzaju. Wstęp - przektad z oryginalu - komentarz, oprac. S. Łach, Poznań 1962.

Lerner R.E., Joachim and the Scholastics, w: Gioacchino da Fiore tra Bernardo di Clairvaux e Innocenzo III. Atti del $5^{\circ}$ Congresso internazionale di studi gioachimiti, San Giovanni in Fiore - 16-21 settembre 1999, red. R. Rusconi, Opere di Gioacchino da Fiore: testi e strumenti, 13, Roma 2001, s. 251-264.

Listy katolickie. Wstęp - przektad z oryginalu - komentarz, red. F. Gryglewicz, Poznań 1959.

McGinn B., ,,Alter Moyses”: il ruolo di Bernardo di Clairvaux nel pensiero di Gioacchino da Fiore, „Florensia. Bollettino del Centro Internazionale di Studi Gioachimiti” 5 (1991), s. 7-25.

McGinn B., Apocalyptic Spirituality. Treatises and Letters of Lactantius, Adso of Montier-en-Der, Joachim of Fiore, the Franciscan Spirituals, Savonarola, London 1980.

McGinn B., L'abate calabrese. Gioacchino da Fiore nella storia del pensiero occidentale, Opere di Gioacchino da Fiore: strumenti, 2, Genova 1990.

McGinn B., Ratio and Visio: Reflections on Joachim of Fiore's Place in Twelfth-Century Theology, w: Gioacchino da Fiore tra Bernardo di Clairvaux e Innocenzo III. Atti del $5^{\circ}$ Congresso internazionale di studi gioachimiti, San Giovanni in Fiore - 16-21 settembre 1999, red. R. Rusconi, Opere di Gioacchino da Fiore: testi e strumenti, 13, Roma 2001, s. 27-46.

McGinn B., Visions of the End. Apocalyptic Traditions in the Middle Ages, New York 1998.

Mottu H., La manifestation de l'Esprit selon Joachim de Fiore. Herméneutique et théologie de l'histoire d'après le „,Traité sur les Quatre Evangiles”, Neuchâtel-Paris 1977.

Patschovsky A., Il diagramma di Gioacchino da Fiore di due alberi Gerusalemme-Babilonia ed Ecclesia-Roma, „Florensia. Bollettino del Centro Internazionale di Studi Gioachimiti” 16-17 (2002-2003), s. 7-23. 
Potestà G.L., Il tempo dell'Apocalisse. Vita di Gioacchino da Fiore, Roma-Bari 2004.

Reeves M., Hirsch-Reich B., The Figurae of Joachim of Fiore, Oxford 1972.

Swieżawski S., Dzieje europejskiej filozofii klasycznej, Warszawa-Wrocław 2000.

Szczurek J.D., Spekulatywna teologia, w: Encyklopedia katolicka, t. 18, red. E. Gigilewicz, Lublin 2013, kol. 658-659.

Jan Grzeszczak - dr hab. teologii, prof. na Wydziale Teologicznym UAM, autor prac z dziedziny filozofii, teologii dziejów i historii Kościoła, zwłaszcza w średniowieczu: Joachim z Fiore. Średniowieczny przyczynek do teologii dziejów (2006), Pomiędzy utopia i eschatologiczna nadzieja. Idea papieża anielskiego $w$ średniowiecznym i renesansowym profetyzmie (2008), Chwila jest bliska. Wizje końca w literaturze profetycznej (XII-XX wiek) (2011). 